\title{
The Potentials of Jatropha Plantations in Egypt: A Review
}

\author{
Waleed Mahmoud Soliman ${ }^{1,2}$, Xiurong $\mathrm{He}^{3}$ \\ ${ }^{1}$ College of Economics \& Management, China Agricultural University, Beijing, China \\ ${ }^{2}$ Agricultural Economics Research Institute, Giza, Egypt \\ ${ }^{3}$ College of Economics \& Management, China Agricultural University, Beijing, China \\ Email: Msoliman.Waleed@gmail.com, hexr@cau.edu.cn
}

Received 15 January 2015; accepted 31 January; published 5 February 2015

Copyright (C) 2015 by authors and Scientific Research Publishing Inc.

This work is licensed under the Creative Commons Attribution International License (CC BY). http://creativecommons.org/licenses/by/4.0/

(c) (i) Open Access

\begin{abstract}
Jatropha curcas $\mathrm{L}$. is one of the recently planted trees that utilizes wastewater in Egypt. It is not just because of its features, such as drought tolerance, rapid growth, and easy propagation, higher oil content than other oil crops, but also because of the Egyptian unique model which uses wastewater for planting Jatropha in the marginal desert land, which in turn represents an excellent opportunity to make use of such land. Moreover, this system provides a good way for reusing the treated sewage water, which itself represents an environment hazard. In addition, Jatropha plantations can be used in the future to be the base for the biodiesel production industry. This review tried to cover the current situation of Jatropha plantations in Egypt. To do so, the paper first reviewed the available land and wastewater resources, and then the potential EU biofuel market situation. Finally, it discussed the biofuel production potentials in Egypt.
\end{abstract}

\section{Keywords}

Wastewater, Jatropha, Biofuel, Environment, Economics, Egypt

\section{Introduction}

As the world seeks a sustainable and green agricultural production on one hand, and seeks sufficient production which can support food security for the growing world population on the other hand, three major problems appears: climate change, pollution and resources limitations. In Egypt, for example, more than $90 \%$ of the total land area is marginal desert land [1], and around $80 \%$ of its limited fresh water amount used by agricultural sector [2], one can see that the limitation of its water resources represents a huge challenge appears in front of any attempt to increase the agricultural land amount in the future. Conversely, as population increases, waste- 
water represents a threat to both of environment and population, and at the same time it also represents a valuable resource which can be used for the sake of the agricultural expansion plans and making use of the marginal desert land. Inappropriately, and according to the health regulations, the treated wastewater cannot be used to irrigate all agricultural crops and plantations, instead it's just used to irrigate a certain kind of trees and crops. Because of that, Egyptian government implemented a wide range of new projects aiming at expanding the green stretch in the desert by introducing forests plantation (man-made forests) which making use of treated sewage water. All of these new projects under one umbrella are called "The National Programme for Safe Use of Treated Sewage Water for Afforestation” [3]. As implementation of this program, Jatropha was planted in many demonstration areas and it really shows excellent results [4], so the idea of stretching the Jatropha plantations to all over available appropriate land area is worthy to study. Furthermore, we can take into consideration the economic value for biodiesel production from Jatropha seeds and all other socio-economic effects that may occur by adopting such industry.

\section{Jatropha around the World}

Jatropha curcas appears to be an ideal plant to produce second-generation biofuels, i.e. manufactured from agricultural or forest residuals and from non-food crop feedstock. J. curcas is suitable for cultivation in marginal and idle lands. Cultivation of the plant for biodiesel production does not induce land-use change, since J. curcas grows in degraded lands, and as a non-food feedstock, it does not compete with agricultural production. A byproduct of oil extraction, e.g., seedcake, produces organic fertilizer through composting that can eventually be used as organic manure. This might reduce $\mathrm{N}_{2} \mathrm{O}$ emissions due to nitrogen-based fertilizers. Finally, J. curcas could represent an opportunity for poor countries to benefit from the growing demand for biofuels [5]. Jatropha curcas L. is a vigorous, drought- and pest-tolerant plant and unpalatable by animals. It is planted in tropical countries principally as a hedge, protecting cropland from the cattle, sheep and goats. Jatropha seed and other plant parts have been used for oil, soap and medicinal compounds. Jatropha is popularized as unique candidate among renewable energy sources due its peculiar features like drought tolerance, rapid growth, and easy propagation, higher oil content than other oil crops. The seed yield reported for Jatropha varies from 0.5 to 12 ton year ${ }^{-1} \cdot \mathrm{ha}^{-1}$ depending on soil, nutrient and rainfall conditions, and the tree has a productive life over 30 years. The seeds contain $30 \%$ - 35\% oil that can be converted into good quality biodiesel by trans-esterification [6]. Jatropha was planted on an estimated 900,000 ha around the world, 760,000 in Asia, 120,000 in Africa and perhaps 20,000 in Latin America. This chimes with what we have learned anecdotally: that up to 1 million ha were planted in a period of 5 years or more to 2010, but of which as much as 800,000 ha had been planted in environments unsuited to commercial cultivation, much of it in India in the form of small holder \& out grower plantings. It is generally accepted that some 800,000 ha was planted out in India, 200,000 ha in Indonesia and other Asian countries including Myanmar and around 100,000 ha in Africa. Some 70\% is estimated to have been planted by small holders. Anecdotal reports indicate that around 200,000 ha have been planted out in suitable areas, again spread over India, Indonesia and Africa principally [7].

Jatropha also has many other uses and benefits which increase its value for rural African communities. One of the reasons for interest in Jatropha is its potential for growth in harsh conditions. Jatropha has already been grown or is being grown in many parts of Africa and requires minimal input and is also easy to propagate [8]. The Jatropha System is an integrated rural development approach. By planting Jatropha hedges to protect gardens and fields against roaming animals, the oil from the seeds can be used for soap production, for lighting and cooking and as fuel in special diesel engines. In this way, the Jatropha System covers 4 main aspects of rural development:

- Promotion of women (local soap production);

- Poverty reduction (protecting crops and selling seeds, oil and soap);

- Erosion control (planting hedges);

- Energy supply for the household and stationary engines in the rural area.

The obvious advantage of this system is that all the processing procedure, and thus all added value, can be kept within the rural area or even within one village. No centralized processing (like the cotton industry) is necessary [9].

\section{Biodiesel Consumption}

Development of biofuels from renewable resources is critical to the sustainability of the world's economy and to 
slow down the global climate change. Currently, a significant amount of bioethanol and biodiesel are produced as biofuels to partially replace gasoline and diesel, respectively, in the transportation sector worldwide. However, these biofuels represent a tiny portion $(<4 \%)$ of the total fuels consumed. Furthermore, bioethanol is produced predominantly from sugarcane and corn, and biodiesel from crop and plant oils [10]. The EU has dominated world biodiesel, whereas the US and Brazil have led fuel ethanol production. World net biofuel trade reached 120 - 130 PJ in 2009 and was directed towards the most lucrative markets. For biodiesel, this has been the EU whose imports rose to $92 \mathrm{PJ}$ in 2008 and remained at $70 \mathrm{PJ}$ in 2009 [11]. The world price of biodiesel (Central Europe FOB) increased to $\$ 4.82$ per gallon in 2008, driven by high demand as EU countries attempted to achieve their biofuel targets and because of high crude-oil prices. Expanded production in Argentina and Brazil led to a temporary price decline, to $\$ 4.40$, in 2009 and a sharp increase in exports before the start of the countries' B5 mandates. However, the world price will increase to $\$ 6.00$ per gallon by 2017 , driven by higher demand from the EU. World net trade doubles to 607 million gallons over the next decade, driven mainly by strong EU demand [12] (Figure 1).

Currently, the EU has the world's most developed biodiesel industry. Production was about 3.3 billion gallons in 2007, and it will reach 4 billion gallons by 2021. Pushed by the biofuel target, domestic consumption continues to grow during the outlook period, reaching 5.0 billion gallons by 2021. Net imports increased rapidly, from 661 million gallons in 2007 to 824 million gallons in 2014 as a sizeable volume of biodiesel was delivered from Argentina and Brazil. Net imports of EU are expected to hit around 1billion gallons at 2021 [13]. (Table 1)

African countries, such as Sudan, have recently started exporting to the EU market, joining countries with a longer history of exports such as Egypt, Malawi and Zimbabwe, with preferential access to EU markets. African countries have excellent potential to increase their exports, assuming that trade reforms and the conditions for investment in Africa continue to improve, this trend seems likely to persist [14]. One more thing to mention, the advantage of the location of Egypt is near EU market, which considers short distance transportation we can neglect the transportation prices changes. As for short distance transport, such as from the Baltic to Sweden, sharp increases in prices may not be a major factor. However, for long-distance transport, such as from Canada to Europe or Australia to China, where shipping is a major component of landed cost, major shipping price increases may be sufficient to cause a source of biomass supply to drop completely out of the market [15].

1200

-European Union $\quad$ Japan

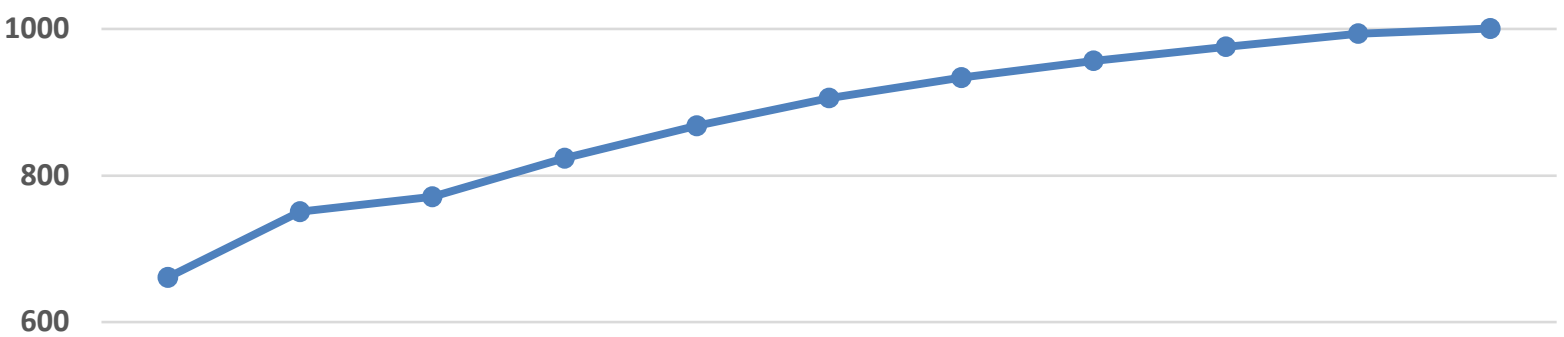

400

200

0

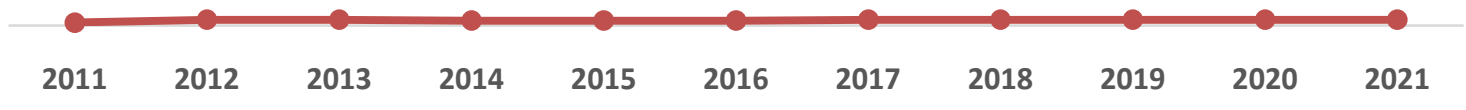

Figure 1. European Union \& Japan biodiesel imports (million gallons). Source: [13]. 
Table 1. European Union biodiesel production and consumption (million gallons). Source: [13].

\begin{tabular}{ccccccccccccc}
\hline Year & $\mathbf{2 0 1 1}$ & $\mathbf{2 0 1 2}$ & $\mathbf{2 0 1 3}$ & $\mathbf{2 0 1 4}$ & $\mathbf{2 0 1 5}$ & $\mathbf{2 0 1 6}$ & $\mathbf{2 0 1 7}$ & $\mathbf{2 0 1 8}$ & $\mathbf{2 0 1 9}$ & $\mathbf{2 0 2 0}$ & $\mathbf{2 0 2 1}$ \\
\hline Production & 3079 & 3191 & 3277 & 3337 & 3422 & 3522 & 3613 & 3712 & 3807 & 3912 & 4022 \\
Consumption & 3731 & 3941 & 4046 & 4160 & 4290 & 4427 & 4547 & 4668 & 4783 & 4906 & 5023 \\
Net Trade & -661 & -751 & -771 & -824 & -868 & -906 & -934 & -957 & -976 & -994 & -1001 \\
\hline
\end{tabular}

\section{Land \& Water Resources in Egypt}

More than 90 percent of Egypt is desert. The total agricultural land base totals about 3.5 million ha (8.4 million feddan) represents about $3.5 \%$ of the total area, which is about 1 million $\mathrm{km}^{2}$ ( 240 million feddan). Of this agricultural land, 3,276,000 ha (7.8 million feddan) lie within the Nile Basin and Delta, and the remaining 210,000 ha $(500,000$ feddan) are rain-fed or in the oases. Of the total area of the Nile Basin and Delta, about 2,268,000 ha (5.4 million feddan) are old lands, the remaining 1,008,000 ha (2.4 million feddan) are new reclaimed lands [1] [16].

In the meanwhile, The River Nile is the main source of water for Egypt with an annual allocated flow of 55.5 $\mathrm{Bm}^{3} / \mathrm{yr}$. under the Nile Waters Agreement of 1959. Internal renewable surface water resources are estimated at $0.5 \mathrm{Bm}^{3} / \mathrm{yr}$. This brings total actual renewable surface water resources to $56 \mathrm{Bm}^{3} /$ year. Internal renewable groundwater resources are estimated at $1.3 \mathrm{Bm}^{3} / \mathrm{yr}$. The overlap between surface water and groundwater is being considered negligible, the total actual renewable water resources of the country are thus $57.3 \mathrm{Bm}^{3} / \mathrm{yr}$. The Nubian Sandstone aquifer located under the Western Desert is considered an important groundwater source, but this is fossil groundwater. The main source of internal recharge is percolation from irrigation water in the Valley and the Delta. All drainage water in Upper Egypt, south of Cairo, flows back into the Nile and the irrigation canals; this amount is estimated at $4 \mathrm{Bm}^{3} / \mathrm{yr}$. Drainage water in the Nile Delta is estimated at $14 \mathrm{Bm}^{3} / \mathrm{yr}$. Treated municipal wastewater in 2001/02 was estimated at $2.97 \mathrm{Bm}^{3} / \mathrm{yr}$. There are several desalination plants on the coasts of the Red Sea and the Mediterranean to provide water for seaside resorts and hotels; total production in 2002 was estimated at 100 million $\cdot \mathrm{m}^{3}$. Estimates of the potential of non-renewable groundwater in the eastern and western deserts, mainly from the Nubian Sandstone aquifer, vary from $3.8 \mathrm{Bm}^{3} / \mathrm{yr}$. to $0.6 \mathrm{Bm}^{3} / \mathrm{yr}$.; the latter estimate is defined as an indicator of exploitability over a period of time, where the time is not given. Total water withdrawal in 2000 was estimated at $68.3 \mathrm{Bm}^{3}$. This included $59 \mathrm{Bm}^{3}$ for agriculture (86\%), $5.3 \mathrm{Bm}^{3}$ for municipalities (8\%) and $4.0 \mathrm{Bm}^{3}$ for industry (6\%) as displayed in Table 2 [2].

The Government of Egypt (GOE) continues to invest heavily in expanding the cultivated area, aiming to add another 3.4 million feddan of cultivated land by the year 2017 in order to secure food for the rapidly increasing population [17]. However, according to the Food and Agriculture Organization of the United Nations estimates, the average needs of agricultural land from water in arid and semi-arid areas—which Egypt located in — should not be less than $5000 \mathrm{~m}^{3} /$ feddan/year for keeping this land away from salinization and loss, because of the warm climate that causes high rate of water evaporation from the land surface. And therefore the amount of water allocated to the agricultural sector in Egypt can hardly used to irrigate areas ranging from 10 to 11 million feddan though about 8.4 feddan of it have already planted and therefore the agricultural expansion under the current water resources can hardly add from 2 to 2.8 million feddan to the current agricultural land, which to be as a total about 11 million feddan [16].

Also it is worth mentioning that the availability of renewable water resources in Egypt has dropped from 2189 $\mathrm{m}^{3} /$ capita/year in 1966 to $1035 \mathrm{~m}^{3} /$ capita/year in 1990. With the current population growth rate, it will even drop more to $536 \mathrm{~m}^{3} /$ capita/year by the year 2025, if the share of Egypt from Nile waters remains as it is today (55.5 $\mathrm{BCM}$ ) and levels of per capita consumption are maintained. Various demands for freshwater are exerting excessive pressure on the available water supply. In a nutshell, the strategic problem Egypt confronts is that its renewable water supplies cannot be expanded (and with the quality issues, available water suitable for some purposes may in fact decline), while at the same time population is growing and the economy is expanding, with associated increases in water requirements. By 2017, the National Water Resource Plan estimates that total water requirements will exceed 90 BCM [18].

\section{Wastewater Status}

Wastewater is the only source of water that increases with the time as population and their activities increase. 
Table 2. Water availability and water use in Egypt (2000). Source: [2].

\begin{tabular}{|c|c|c|c|}
\hline Water Input & Million $\mathrm{m}^{3} / \mathrm{yr}$ & Water Use & Million $\mathbf{m}^{3} / \mathbf{y r}$ \\
\hline Renewable Surface Water Resources & 56,000 & Agriculture & 59,000 \\
\hline Renewable Ground Resources & 2300 & Domestic & 5300 \\
\hline Reuse of Agricultural Drainage Water (Return Flow to Rivers) ${ }^{*}$ & 4840 & Industry & 4000 \\
\hline Reuse of Groundwater (Seepage from Agriculture) ${ }^{*}$ & 6127 & & \\
\hline Reuse Treated Wastewater & 2971 & & \\
\hline Desalinated Water & 100 & & \\
\hline Use of Fossil Groundwater (Non-Renewable Water) & 825 & & \\
\hline Total & 73,163 & Total & 68,300 \\
\hline Navigation \& Hydropower & & & 4000 \\
\hline
\end{tabular}

*Total water returning from agriculture was about $18 \mathrm{~km}^{3}$, of which about $12 \mathrm{~km}^{3}$ was return flow to rivers and $6 \mathrm{~km}^{3}$ seepage to groundwater.

And to make use of this source, the Holding Company for Water and Wastewater (HCWW) was established by presidential decree No. 135/2004 in 2004. The purpose the Holding Company set by a Presidential Decree is to purify, desalinate, distribute and sell drinking water and collect, treat and safely dispose of wastewater, either itself or through affiliate companies [19] [20]. Egypt's Holding Company for Water and Wastewater owns and operates all of Egypt's 372 municipal wastewater treatment plants, treating an average of $10.1 \mathrm{million} \mathrm{m}^{3} / \mathrm{d}$ of sewage [21]. Although sanitation covers more than 95\% in urban areas of Egypt, it still covers less than 15\% in rural areas and the rest of the rural areas still use septic tanks, and latrines [22]. It estimates that around EGP80 billion ( $\$ 13$ billion) of investment in wastewater collection and treatment would be needed to achieve full coverage for the countryside [21]. Table 3 below presents the production capacity and investment in wastewater projects over the period of time and as expected until year 2012 [23].

It's a big investment for a developing country such as Egypt, but since the untreated sewage can represent a threat to the public health and the environment in general, it has to be done and a small drop of fecal matter can contain millions of microorganisms of many types, some of which are pathogenic. Microbial pathogens in raw or inadequately treated sewage can cause illnesses ranging from temporary stomach cramps to life-threatening conditions such as inflammation of the heart. While, for the healthy population, most of the illnesses resulting from exposure to inadequately treated sewage are relatively minor (respiratory illness; ear, nose or throat irritation; gastroenteritis), they can become serious in more vulnerable populations, including pregnant women, young children, the elderly, and people with suppressed immune systems (such as people with HIV, transplant recipients, and cancer patients) [24].

However, the current amount of collected wastewater in Egypt is about 6.5 Billion $\cdot \mathrm{m}^{3} / \mathrm{yr}$., of which about $56 \%$ (3.65 Billion $\cdot \mathrm{m}^{3} / \mathrm{yr}$.) is treated, and the rest of wastewater which around $2.85 \mathrm{Billion} \cdot \mathrm{m}^{3} / \mathrm{yr}$. is not treated. Anyway, use of treated wastewater has become increasingly important in water resources management for both environmental and economic reasons. Wastewater use in Egypt is an old practice. It has been used since 1930 in sandy soil areas like Al-Gabal, Al-Asfar and Abou Rawash, near Cairo. Interest in the use of treated wastewater, as a substitute for fresh water in irrigation, has accelerated since 1980. Currently, the treated wastewater divided into two types, the first is primary treated and it's about $20 \%$ of the total treated wastewater about 0.73 Billion $\cdot \mathrm{m}^{3} / \mathrm{yr}$. and the second is secondary treated about 2.92 Billion $\cdot \mathrm{m}^{3} / \mathrm{yr}$., but only 0.7 Billion $\cdot \mathrm{m}^{3} / \mathrm{yr}$. of treated wastewater is being used in irrigation, of which 0.26 Billion $\cdot \mathrm{m}^{3} / \mathrm{yr}$. (secondary treated) and $0.44 \mathrm{Billion} \cdot \mathrm{m}^{3} / \mathrm{yr}$. (primary treated) to cultivate forests \& some crops. The rest amount of the treated wastewater which about 2.95 Billion $\cdot \mathrm{m}^{3} / \mathrm{yr}$. is pumped to drains \& canals in Cairo \& Delta [18] [22].

Wastewater has been used to support the agricultural production in many countries such as USA, Germany, India, Kuwait, Saudi Arabia, Oman, Jordan and Tunisia. Several investigators indicated the beneficial role of wastewater in increasing crop yields without or with minimal risks to the plant, soil, groundwater and health [25]. It is generally accepted that wastewater use in agriculture is justified on agronomic and economic grounds but care must be taken to minimize adverse health and environmental impacts [26]. According to this fact the Egyptian government published "The Egyptian Code for the Reuse of Treated Municipal Wastewater in Agri- 
Table 3. Production capacity and investment in wastewater projects. Source: [23].

\begin{tabular}{cccc}
\hline Item & $\begin{array}{c}\text { Production Capacity } \\
\left(\mathbf{1 , 0 0 0 , 0 0 0} \mathbf{~ M}^{\mathbf{3}} \mathbf{\text { D) }}\right.\end{array}$ & $\begin{array}{c}\text { Average Per Capita } \\
\text { Share (L/D) }\end{array}$ & $\begin{array}{c}\text { Investment Implemented } \\
\text { (LE Billion) }\end{array}$ \\
\hline Till 1982 & 1.1 & 25 & 0.8 \\
Till 2007 & 11 & 150 & 40 \\
Till 2012 & 28 & 230 & 54 \\
\hline
\end{tabular}

culture" and The code was approved by Ministerial Decree No. 171/2005, Ministry of Housing. The code regulates and classifies plants and crops Irrigable with treated municipal wastewater as Table 4 illustrates [4].

Also from Table 5, we may note that C is primary treatment, B is secondary treatment and A is advanced treatment, and these grades determined as Table 4 shows.

However, expansion of treated wastewater reuse in the region is linked to a number of issues and constraints. The high cost of treatment and management of reclaimed wastewater is one of the major limitations facing the weak economy of most countries. Unclear polices, institutional conflicts and lack of regulatory frameworks constitute other important constraints that hinder implementation and proper operation of wastewater reuse projects [28].

\section{Energy in Egypt}

Over the years, the power sector has always played a substantial role in enhancing economic development in Egypt via securing the domestic energy demand for electricity. Limited primary energy resources are available in Egypt with varying potentialities. The most important of these resources are oil, natural gas, and hydropower. In addition, renewable energy resources, particularly solar and wind, have a good potential [29]. In Egypt, crop residues are considered to be the most important and traditional source of domestic fuel in rural areas. These crop residues are by-products of common crops such as cotton, wheat, maize and rice. The total amount of residues reaches about 16 million tons of dry matter per year. Cotton residues represent about $9 \%$ of the total amount of residues and the materials are mainly comprised by cotton stalks, which present a disposal problem. The area of cotton crop cultivation accounts for about 5\% of the cultivated area in Egypt [30]. Egypt's energy sector, specifically its electricity, oil and natural gas subsectors, is a large, important and promising part of the national economy. Egypt faces the challenges of growth in population, energy demand, and the energy production needed to meet its modern development goals. The economy is energy-intensive, especially the manufacturing and tourism components that together represented about 25 percent of GDP in recent years [31]. Egypt is the largest oil and natural gas consumer in Africa, accounting for more than $20 \%$ of total oil consumption and more than $40 \%$ of total dry natural gas consumption in Africa in 2013. Energy subsidies, which cost the government \$26 billion in 2012, have contributed to rising energy demand and a high budget deficit [32] (Figure 2).

In 1986, Egypt's New \& Renewable Energy Authority (NREA) was established to act as the national focal point for expanding efforts to develop and introduce renewable energy technologies on a commercial scale. Since then, a number of governmental organizations have been set up to help promote and develop policies to encourage the growth of the renewable energy industry. Egypt's present energy strategy (adopted by resolution of the SCE in February 2008) aims at increasing the share of renewable energy to 20 percent of Egypt's energy mix by 2020 [33].

\section{Jatropha in Egypt}

In Egypt, There is particular interest in using forest plantations as a means of addressing a number of key environmental priorities, including the safe use of primary treated municipal wastewater and for combating desertification. These environmental aims are also compatible with biomass feedstock production for possible future ligno-cellulosic ethanol production [34]. As a start, more than 160,000 feddan (67,200 ha) are available for plantations [35]. Mainly all of this area is marginal desert land and for now as a start around 88,000 feddan (36,960 hectare) is allocated to the Holding Company for Water and Wastewater for reuse projects in different governorates, around 11,000 feddan (4620 hectare) of the total allocated area already cultivated with various plantations [22]. Table 6 shows different locations of treated wastewater reuse. 
Table 4. Egyptian code for plants \& crops irrigable with treated wastewater. Source: [4].

\begin{tabular}{|c|c|c|}
\hline Grade & Agricultural Group & \\
\hline A & $\begin{array}{l}\text { G1-1: Plants and trees grown for greenery at tourist villages and hotels. } \\
\text { G1-2: Plants and trees grown for greenery inside residential areas at the } \\
\text { new cities. }\end{array}$ & $\begin{array}{l}\text { Grass, Saint Augustine grass, cetaceous plants, } \\
\text { ornamental palm trees, climbing plants, } \\
\text { fencing bushes and trees, wood trees and } \\
\text { shade trees. }\end{array}$ \\
\hline \multirow{7}{*}{ B } & G2-1: Fodder/Feed crops & Sorghum sp. \\
\hline & G2-2: Trees producing fruits with epicarp. & $\begin{array}{l}\text { On condition that they are produced for } \\
\text { Processing purposes such as lemon, mango, } \\
\text { date palm and almonds. }\end{array}$ \\
\hline & $\begin{array}{l}\text { G2-3: Trees used for green belts around cities and afforestation of } \\
\text { high waysorroads }\end{array}$ & $\begin{array}{l}\text { Casuarina, camphor, athel tamarix (salt tree), } \\
\text { oleander, fruit-producing trees, date palm and } \\
\text { olive trees. }\end{array}$ \\
\hline & G2-4: Nursery plants & $\begin{array}{l}\text { Nursery plants of wood trees, ornamental } \\
\text { plants and fruit trees }\end{array}$ \\
\hline & G2-5: Roses \& cut flowers & Local rose, eagle rose, onions (e.g. gladiolus) \\
\hline & G2-6: Fiber crops & Flax, jute, hibiscus, sisal \\
\hline & G2-7: Mulberry for the production of silk & Japanese mulberry \\
\hline \multirow{2}{*}{ C } & G3-1: Industrial oil crops & Jojoba, castor-oil plant, and Jatropha \\
\hline & G3-2: Wood trees & Kaya, camphor and other wood trees. \\
\hline
\end{tabular}

Table 5. Wastewater treatment grades. Source: [27].

\begin{tabular}{ccccc}
\hline \multicolumn{1}{c}{ Treatment Grade Requirements } & A & B & C \\
\hline Effluent limit values for BOD and SS & BODs & $<20$ & $<60$ & $<400$ \\
& SS & $<20$ & $<50$ & $<250$ \\
$\begin{array}{c}\text { Effluent limit value for fecal coliform and nematode } \\
\text { cells or eggs (per liter) }\end{array}$ & Fecal coliform count in $100 \mathrm{~cm}^{3}$ & $<1000$ & $<5000$ & Unspecified \\
& Count of nematode cells or eggs per liter & $<1$ & $<1$ & Unspecified \\
\hline
\end{tabular}

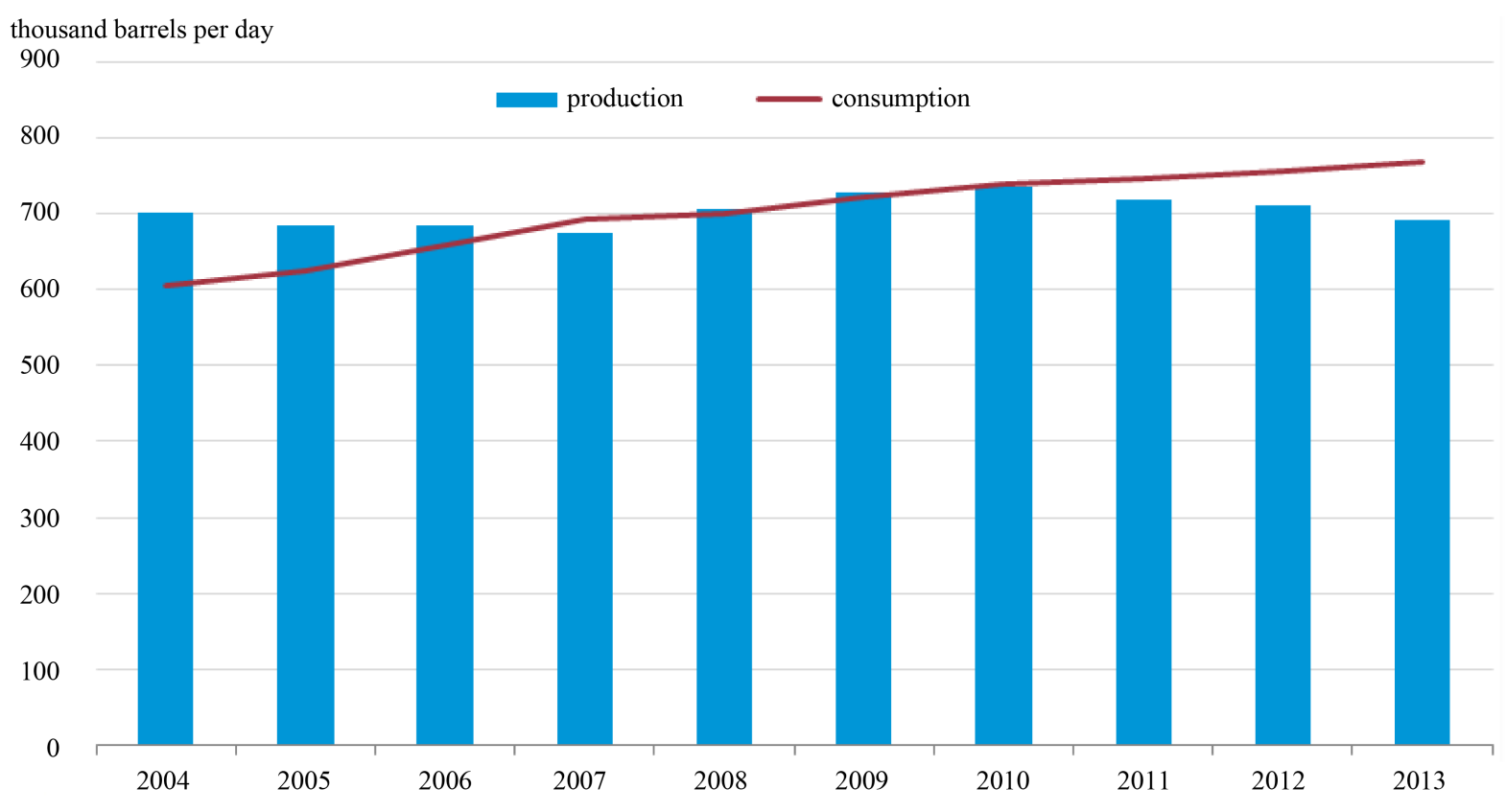

Figure 2. Petroleum and other liquids production \& consumption in Egypt. 
Many plants and crops cultivated in the above mentioned area and Jatropha is one of them (Table 6). The Jatropha experiment started in Egypt in 1997 on small scale, using Jatropha curcas seed imported from India. Promising results prompted the Egyptian Government to plant this species using seed from India on a wider scale, including the establishment of 42 hectares of Jatropha in 2001, irrigated by treated sewage water (drip irrigation). All desert areas of Upper Egypt governorates and in the New Valley are considered potentially suitable for Jatropha plantations. Such marginal land which has been planted with Jatropha in Egypt presently covers 844 hectares [36]. And it distributed over many areas as Figure 3 shows.

Table 6. Locations of treated wastewater reuse. Source: [4].

\begin{tabular}{cccc}
\hline Governorate & WWT Plants Total Capacity ('000 cu MT) & Total Available Land Area (Feddan) & Designated \\
\hline 6 October & 500 & 53,800 & Yes \\
Alexandria & 1373 & 70,000 & Yes \\
Beheira & & 625 & Yes \\
Matrouh & 25 & 3007 & only 500 \\
Menoufiya & 45 & 1600 & Since 1999 \\
North Sinai & 50 & 4000 & Since 1991 \\
South Sinai & 775 & 1019 & Since 2005 \\
Ismailia & 100 & 1060 & Since 2008 \\
Beni Sewaef & 124 & 2163 & Yes \\
Menya & 240 & 7000 & Since 1963 \\
Fayoum & 92 & 345 & Since 1998 \\
Assiout & 226 & 12,467 & Since 1999 \\
New valley & 84 & 4711 & Yes \\
Sohag & 284 & 18,325 & Yes \\
Qena & 249 & 17,021 & Since 1999 \\
Aswan & 107 & 2469 & 2086 \\
Luxor & 46 & 2994 & $\mathbf{2 0 4 , 6 9 2}$ \\
Red Sea & & & \\
Total & & & \\
\hline
\end{tabular}

${ }^{*}$ Governorates only have available lands for reuse.

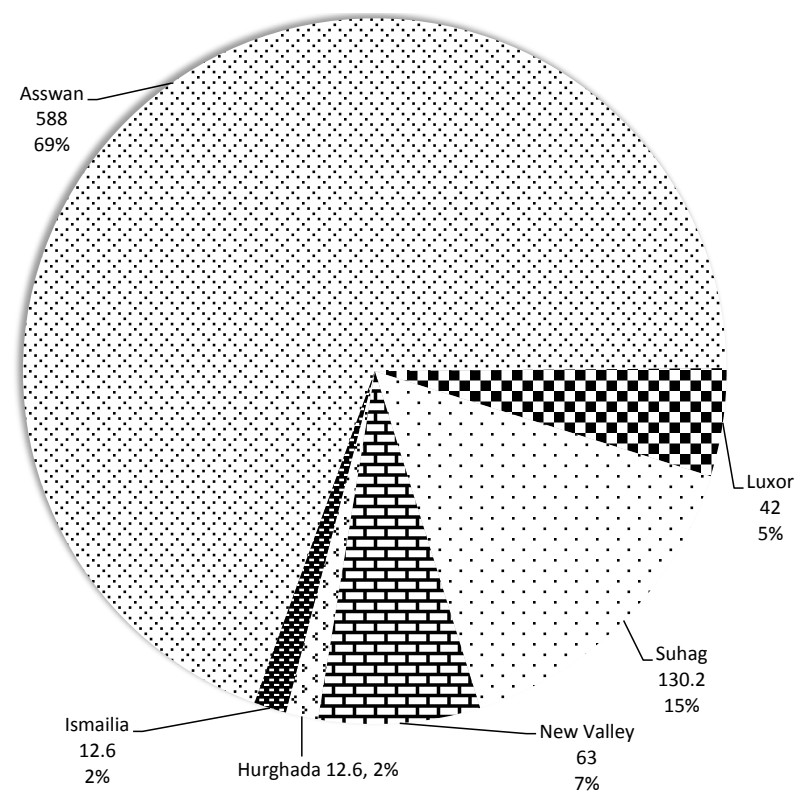

Figure 3. Land area cultivated by Jatropha. Source: [36]. 
In 2008, a feasibility study was made about Jatropha plantations in Luxor by Dr. Imam El Gamassy, and among his results on the national level was that Jatropha, as a source of biofuel, must be part of the renewable energy strategy in Egypt. Plans to promote its use should be taken seriously. And all expansion areas for Jatropha plantation must be near treated wastewater plants in the desert or on marginal lands. Its cultivation must be totally prohibited on agricultural lands. Moreover, Jatropha cultivation should be a government-controlled activity to protect agricultural lands from being used, as they might be if left under private sector management. And at last, the Jatropha biodiesel industry should be planned and established as a national fuel resource as the traditional ones (oil and gas) [37].

In 2009 Dr. Kenneth Swanberg made a study about "Alternative Crops with Potential for The Reuse of Treated Wastewater in Egypt”. In his study, he tried to identify which one or combination of the crops mentioned earlier might have possibilities for generating significant financial returns for the use of treated wastewater in the allocated area which mentioned in the previous section. One of his key finding was that Jatropha curcas, oil seed crop that is known to be one of the more promising bio-diesel fuel oil crops. Jatropha is grown at several sites, with varying degrees of productivity. However, new plantings at Luxor and Abu Rawash look extremely promising, with earlier than expected yields. With the higher and earlier yields, Jatropha becomes an economically viable crop. In-country processing of bio-diesel is projected and highly recommended in order to capture the full value-added processing income of this crop. He also said, "The real opportunity for Egypt is to grow Jatropha using treated wastewater. Since Jatropha is not edible, and in fact is used as a deterrent to animals in hedgerows, and in some instances as pesticide, it is perfectly suited for use of wastewater. In addition, the wastewater is nutritious for the plant, with nitrogen and other chemicals, and at the wastewater sites, there is plenty of water to be disposed of on the plants, assuring that they will be amply watered. Some of the initial test sites for Jatropha took 2 years to grow fruit, but the recent plantings have borne fruit within the first year. This is very promising." [4].

\section{Potentials of Jatropha Plantations}

After this review discussed many resources and aspects related to Jatropha plantations in Egypt, now we can conclude the opportunities for Jatropha plantations in Egypt and biodiesel production in the following points.

- The European Union - the world's largest biofuel market - they target to reach $10 \%$ for the use of renewable energy in road transport fuels by 2020 [38], and such policy is very promising because it will give the chance to the Egyptian biodiesel to compete in the EU market, especially if we take into consideration the distance between the two markets.

- The plantation of Jatropha also works for Clean Development Mechanism (CDM) promoted by the Kyoto Protocol. For example, under the Kyoto Protocol, Japan needs to reduce its greenhouse gas (GHG) emissions about 12 billion tons between 2008 and 2012, which is 6\% of the 1990 emission level. However, the actual GHG emissions in 2006 exceeded more than the double of the allowance. The former Prime Minister Abe appealed to reduce $50 \%$ of the world GHG emission by 2050, but Japan should prove its responsibility and reliability with Kyoto treaty at first before the high and long term promising. This unique Egyptian biofuel model_-biofuel from wastewater and waste land—can be a good opportunity for a Japanese contribution to the global warming mitigation outside of Japan. By our rough assumption for the Egyptian model, 1 million hectors of Jatropha plantation is expected to produce 1 million ton of BDF. This 1 million ton of BDF usage would reduce 2 million tons of $\mathrm{CO}_{2}$ emission. Annually, a value of 28 million US\$ market would be delivered. The Egyptian actual profits from the carbon trading would be one-half or one-third of the expected value [39].

- Jatropha plantations could cause some impacts on the society as well, as most of the potential suitable area for Jatropha plantations located in Upper Egypt, which is less developing, more rural and poorer than any other area in Egypt, moreover most of labor from this area migrates to Lower Egypt [40] which is represent major problem now. Also the biodiesel production can offer more job opportunities and make overall developing in this area.

\section{Conclusion}

In 1997, the Egyptian government started Jatropha plantations experiment as part from "The National Program for Safe Use of Treated Sewage Water for Afforestation” which aims to expand the green stretch in the desert by 
introducing forests plantation (man-made forests) and to produce high economic value trees by making use of treated sewage water. Moreover, giving that more than 90 percent of Egypt is desert [1], and that only only 0.7 Billion $\cdot \mathrm{m}^{3} / \mathrm{yr}$. out of 3.65 Billion $\cdot \mathrm{m}^{3} / \mathrm{yr}$. of the treated wastewater is being used in irrigation [18]. One the other hand, the River Nile is the main source of water for Egypt with an annual allocated flow of $55.5 \mathrm{Bm}^{3} / \mathrm{yr}$ [2]. According to these facts, we can see the opportunity of Jatropha plantations \& biodiesel production and we know that Jatropha gives higher and earlier yields in Egypt [4]. In addition, the increase in EU imports of biodiesel [13] can create a huge market for the Egyptian biodiesel in the future.

\section{References}

[1] El-Nahrawy, D.M.A. (2011) Country Pasture Profiles, Egypt. http://www.fao.org/ag/AGP/AGPC/doc/Counprof/Egypt/Egypt.html

[2] AQUASTAT (2009) FAO’s Information System on Water and Agriculture. http://www.fao.org/nr/water/aquastat/countries_regions/EGY/index.stm

[3] Ministery of State for Environmental Affairs, the Egyptian Environmental Affairs Agency (EEAA) (2012) Forest Plantation. http://www.eeaa.gov.eg/English/main/env_forests.asp

[4] Swanberg, K. (2009) Economic Feasibility of Alternative Crops with Potential for the Reuse of Treated Wastewater in Egypt. International Resources Group, Washington DC.

[5] Basili, M. and Fontini, F. (2012) Biofuel from Jatropha curcas: Environmental Sustainability and Option Value. Ecological Economics, 78, 1-8. http://dx.doi.org/10.1016/j.ecolecon.2012.03.010

[6] Pandey, V.C., Singh, K., Singh, J.S., Kumar, A., Singh, B. and Singh, R.P. (2012) Jatropha curcas: A Potential Biofuel Plant for Sustainable Environmental Development. Renewable and Sustainable Energy Reviews, 16, 2870-2883. http://dx.doi.org/10.1016/j.rser.2012.02.004

[7] Doug, H. and Chen, Y.H. (2012) Jatropha-Plant with a Future. Hardman \& Co., London.

[8] Eckart, K. and Henshaw, P. (2012) Jatropha curcas L. and Multifunctional Platforms for the Development of Rural Sub-Saharan Africa. Energy for Sustainable Development, 16, 303-311.

[9] Robinson, S. and Beckerlegge, J. (2008) Jatropha in Africa Economic Potential. http://www.jatropha.pro/publications.htm.

[10] Cheng, J.J. and Timilsina, G.R. (2011) Status and Barriers of Advanced Biofuel Technologies: A Review. Renewable Energy, 36, 3541-3549. http://dx.doi.org/10.1016/j.renene.2011.04.031

[11] Patrick, L., Carlo, H., Martin, J. and André, F. (2011) International Bioenergy Trade-A Review of Past Developments in the Liquid Biofuel Market. Renewable and Sustainable Energy Reviews, 15, 2655-2676. http://dx.doi.org/10.1016/j.rser.2011.01.022

[12] Food and Agricultural Policy Research Institute (2008) World Agricultural Outlook. FAPRI, Columbia.

[13] The National Institute of Food and Agriculture (2012) World Agricultural Outlook. FAPRI-ISU, Columbia.

[14] Francis, X.J., Henrique, P. and Edward, S. (2012) Transformations in EU Biofuels Markets under the Renewable Energy Directive and the Implications for Land Use, Trade and Forests. Center for International Forestry Research, Bogor.

[15] Bradley, D., Diesenreiter, F., Wild, M. and Tromborg, E. (2009) World Biofuel Maritime Shipping Study. IEA Bioenergy, Vienna.

[16] Half World Magazine (2011) Egypt and Biofuel Production System. http://digital.ahram.org.eg/Community.aspx?Serial=531247

[17] Behery, A.E. (2005) Design of Irrigation Network for Demonstration Site at Luxor. LIFE Integrated Water Resources Management, Cairo.

[18] Wahaab, R.A. and Mohy El-Din, O. (2011) Wastewater Reuse in Egypt: Opportunities and Challenges. http://www.arabwatercouncil.org/index.php

[19] Moawad, A. (2011) Water and Sanitation Sector Reform in Egypt. http://www.worldwaterweek.org/sa/node.asp?node=1079

[20] Holding Company For Water and Waste (2008) Company Role. http://www.hcww.com.eg/en/Content.aspx?ID=2

[21] Global Water Intelligence (2012) Wastewater Focus Moves out of the City. http://www.globalwaterintel.com/archive/13/11/general/wastewater-focus-moves-out-city.html

[22] Wahaab, R.A. (2012) Wastewater Reuse in Egypt: Opportunities and Challenges. IFAT Entsorga, Messe München. 
[23] Ministry of Housing (2009) 6th of October Wastewater Treatment Plant-Confidential Information Memorandum. Ministry of Housing, Cairo.

[24] Dorfman, M. (2004) Swimming in Sewage. Natural Resources Defense Council, New York.

[25] Lateef, E.M.A.E., Hall, J.E., Farrag, M.A.A. and Farrag, A.A. (2011) Agro-Economic Studies on Wastewater Reuse in Developing Marginal Areas in West Delta, Egypt. International Journal of Water Resources and Arid Environments, 2, 110-115.

[26] Pescod, M. (1992) Wastewater Treatment and Use in Agriculture-FAO Irrigation and Drainage Paper 47. Food and Agriculture Organization of the United Nations, Rome.

[27] ECODIT, Inc. (2008) Environmental Evaluation of Using Treated Wastewater in Agriculture: Luxor Demonstration Site. International Resources Group, Washington DC.

[28] Bazza, M. (2002) Wastewater Reuse in the Near East Region: Experience and Issues. Food and Agriculture Organization of the United Nations, Location.

[29] Bedrous, M.A. (2007) Egypt Country Report. World Energy Council, London.

[30] Zafar, S. (2014) Bioenergy Resources in MENA Countries, Egypt. BioEnergy Consult. http://www.bioenergyconsult.com/tag/egypt/

[31] Shafey, T. (2012) Why Integrated Policies Are Vital for Egypt’s Energy Future. Economywatch. http://oilprice.com/Energy/Energy-General/Why-Integrated-Policies-are-Vital-for-Egypts-Energy-Future.html

[32] EIA (2014) Egypt Analysis. US Energy Information Administration. http://www.eia.gov/countries/cab.cfm?fips=EG

[33] Croker, A. (2013) Renewable Energy in Egypt: Hydro, Solar and Wind. Norton Rose Fulbright. http://www.nortonrosefulbright.com/knowledge/publications/74735/renewable-energy-in-egypt-hydro-solar-and-wind

[34] Agra CEAS Consulting (2009) Potential for Biofuel Production in FEMIP Countries FTF/REG/04/2006. European Investment Bank, Luxembourg.

[35] Zalesny Jr., R.S., Stanturf, J.A., Evett, S.R., Kandil, N.F. and Sorianos, C. (2011) Opportunities for Woody Crop Production Using Treated Wastewater in Egypt. I. Afforestation Strategies. International Journal of Phytoremediation, 13, 102-121.

[36] Hayder, M. and Rakotondramanga, S. (2011) Oil Trees for Energy in the near East Region. Food and Agriculture Organization, Cairo.

[37] Gamassy, D.I.E. (2008) Feasibility Study on Growing Jatropha Utilizing Treated Wastewater in Luxor. International Resources Group, Washington DC.

[38] GLOBE-Net (2011) Media Corner. http://www.ebb-eu.org/media.php

[39] Japan Bio-Energy Development Corp. (2007) Projects Report. http://jbedc.com/en/projects-2.html

[40] Zohry, A.G. (2002) Rural-to-Urban Labor Migration: A Study of Upper Egyptian Laborers in Cairo. Unpublished DPhil. Thesis, University of Sussex, Brighton. 
Scientific Research Publishing (SCIRP) is one of the largest Open Access journal publishers. It is currently publishing more than 200 open access, online, peer-reviewed journals covering a wide range of academic disciplines. SCIRP serves the worldwide academic communities and contributes to the progress and application of science with its publication.

Other selected journals from SCIRP are listed as below. Submit your manuscript to us via either submit@scirp.org or Online Submission Portal.
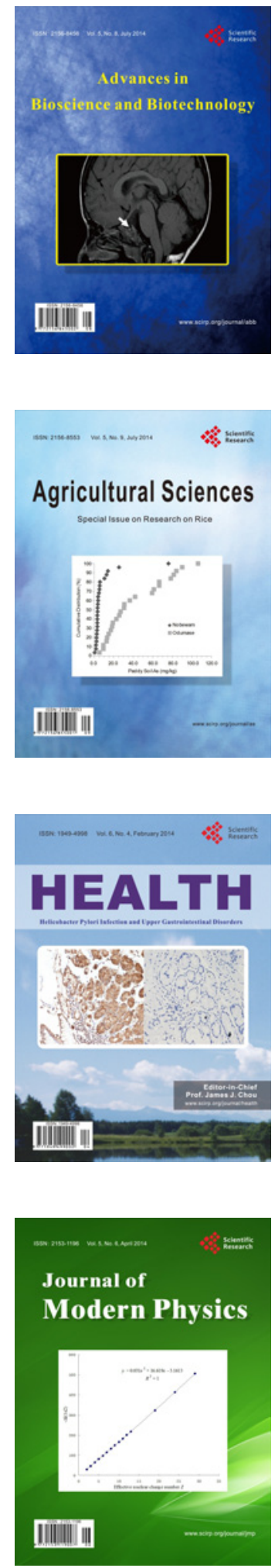
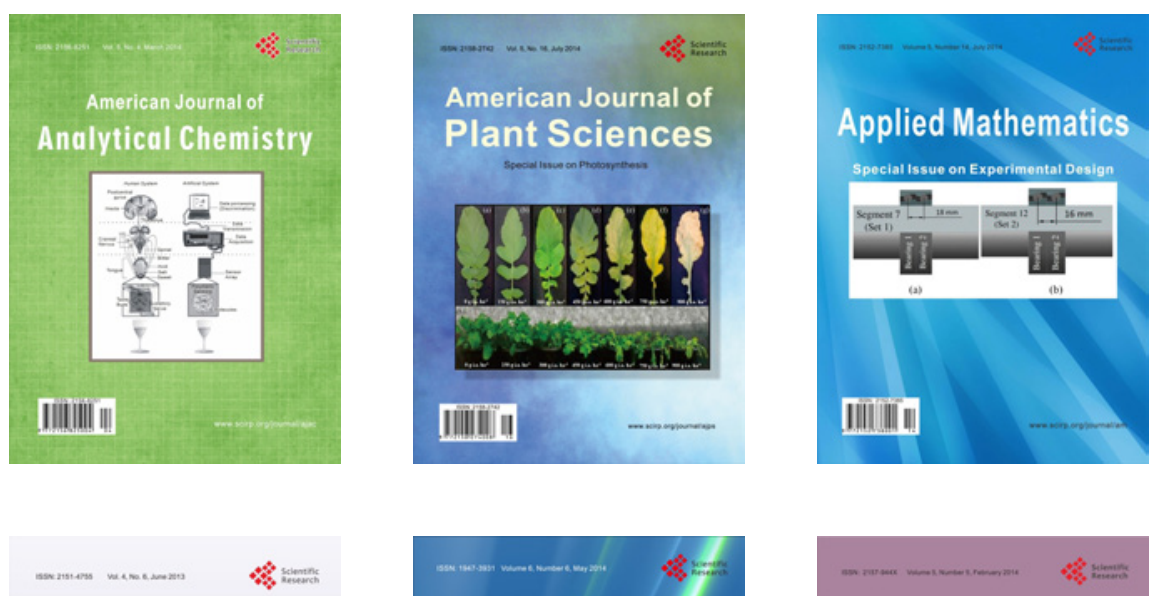

Creative Education
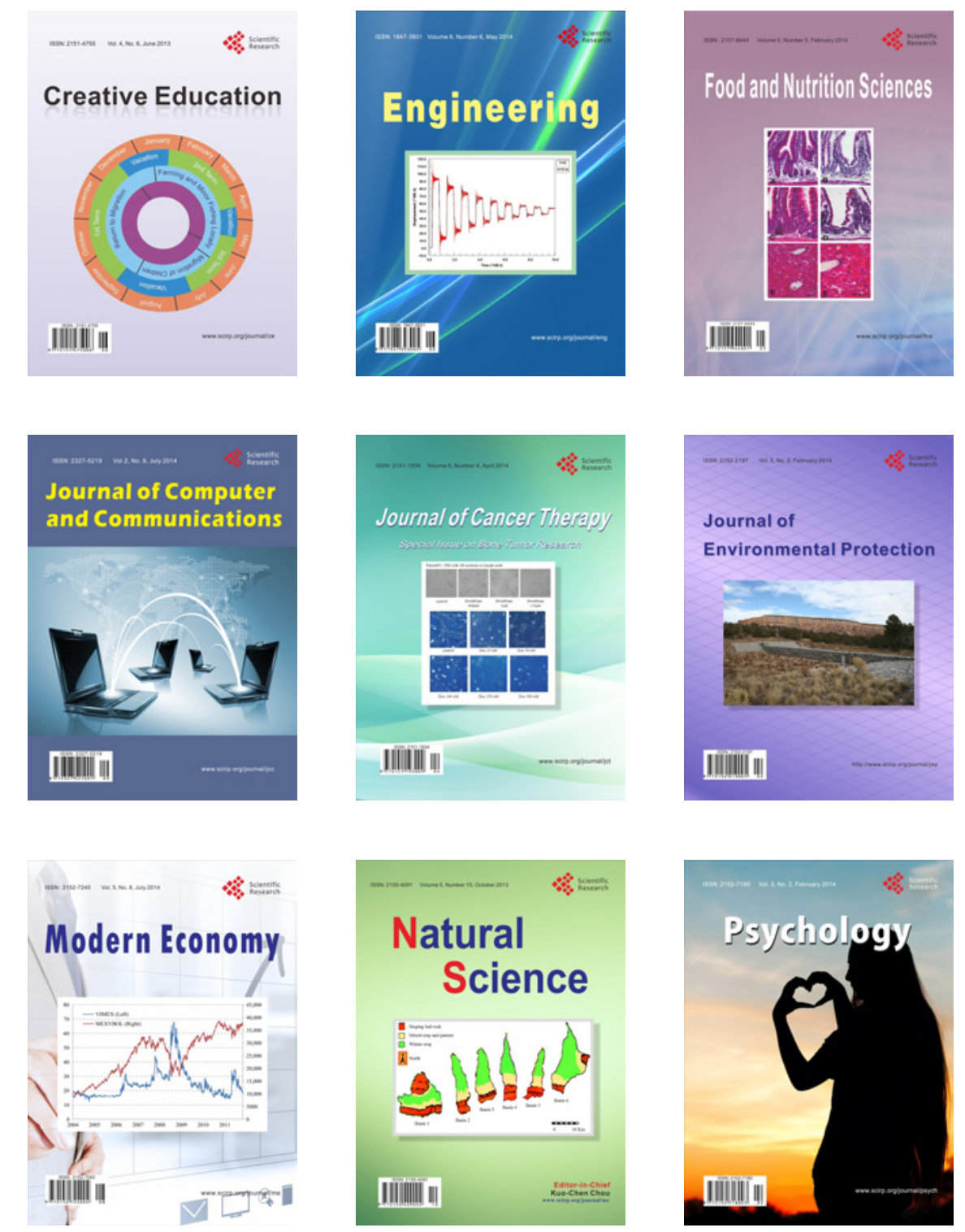